\title{
Klasifikasi Microarray "Prostate Cancer" Menggunakan Metode Fuzzy Support Vector Machine (FSVM)-Genetic Algorithm
}

\author{
Cicilia Ajeng Pratiwi dan Irhamah \\ Departemen Statistika, Fakultas Matematika, Komputasi, dan Sains Data (FMKSD) \\ Institut Teknologi Sepuluh Nopember (ITS) \\ e-mail: irhamah@statistika.its.ac.id
}

\begin{abstract}
Abstrak-Salah satu jenis kanker yang yang menjadi penye-bab terbanyak kematian pada populasi pria adalah kanker prostat. Penyakit ini hanya terdapat pada pria karena pada wanita tidak memiliki kelenjar prostat. Secara global, kanker prostat menduduki urutan keempat, kanker yang paling sering ditemukan pada manusia setelah kanker payudara, paru dan kolorektum. sedangkan angka kejadian kanker pada pria, kanker prostat menduduki urutan ke-2. Pada umumnya penderita baru mengetahui penyakit tersebut sudah memasuki stadium lanjut. Terlambatnya penanganan pada penderita prostate bisa berakibat fatal bahkan dapat menyebabkan kematian. Oleh karena itu,penyakit kanker prostat sangat penting untuk didiagnosis sedini mungkin sebelum penyebaran sel kanker ke organ internal. Pada perkembangan saat ini, terdapat teknologi microarray yang memiliki pengaruh besar dalam menentukan gen informatif menyebabkan kanker. Penelitian ini mengguna-kan data microarray "prostate cancer". Ekspresi gen yang ter-dapat pada data microarray "prostate" dapat digunakan untuk mengklasifikasikan pasien yang mengalami tumor prostat dan normal. Penelitian ini diperoleh hasil klasifikasi Fuzzy Support Vector Machine (FSVM)dengan menggunakan seleksi Fast Correlation Based Filter(FCBF) tanpa optimasi genetic algorithm menghasilkan nilai akurasi lebih tinggi dibandingkan tanpa seleksi. Selain itu, diperoleh juga nilai akurasi klasifikasi FSVM dengan menggunakan seleksi dan optimasi genetic algorithm lebih tinggi dibandingkan tanpa seleksi.
\end{abstract}

Kata Kunci-Fast Corelation Based Filter, Fuzzy Support Vector Machine, Genetic algorithm, Microarray.

\section{PENDAHULUAN}

$\mathrm{P}$ ENYAKIT kanker merupakan salah satu penyebab kematian utama di seluruh dunia. Pada tahun 2012, penyakit kanker menjadi penyebab kematian sekitar 8,2 juta orang [1]. Salah satu jenis kanker yang yang menjadi penyebab terbanyak kematian pada populasi pria adalah kanker prostat. Penyakit ini hanya terdapat pada pria karena pada wanita tidak memiliki kelenjar prostat. Kanker prostat menduduki urutan ke-2 yaitu sekitar $14,8 \%$ setelah kanker paru $16,8 \%$. Pada tahun 2012 kejadian kanker prostat menempati urutan ke-3 kanker pada pria setelah kanker paru dan kanker kolorektum, sedangkan angka kematian menempati urutan ke-4 di Indonesia [2].

Data di USA menunjukkan bahwa lebih dari $90 \%$ kanker prostat ditemukan pada stadium dini,sedangkan di Indonesia banyak ditemukan pada stadium lanjut karena terjadi keterlambatan diagnosis [2]. Oleh karena itu,penyakit kanker pros- tat sangat penting untuk didiagnosis sedini mungkin sebelum penyebaran sel kanker ke organ internal. Pada perkembangan saat ini, terdapat teknologi microarray yang memiliki pengaruh besar dalam menentukan gen informatif yang menyebabkan kanker.

Micorarray mampu menentukan ekspresi ribuan gen dan secara simultan memantau proses biologis yang sedang berlangsung [3]. Microarray merupakan bagian dari high dimensional data karena memiliki ratusan sampai dengan ribuan fitur [4]. Namun permasalahan yang terjadi adalah data microarray mempunyai jumlah variabel yang lebih besar dibandingkan dengan jumlah observasinya. Oleh karena itu, perlu dilakukan seleksi variabel dengan menggunakan metode fast correlation based filter untuk menyelesaikan permasa-lahan klasifikasi.

Penelitian sebelumnya telah melakukan analisis dan implementasi feature selection menggunakan algoritma Fuzzy Support Vector Machine(FSVM). Hasil dari penelitian tersebut adalahfeature selectiontipe wrapper dengan menggunakan metode Fuzzy Support Vector Machine dimana feature selection dilakukan bersamaan dengan pemodelan dan evaluasi feature berdasarkan classification rate yang dihasilkan oleh classifier yaitu Fuzzy Support Vector Machine. Semakin baik parameter FSVM maka hasil feature selection juga akan semakin baik berbanding lurus dengan hasil klasifikasi [5].Berdasarkan penelitian mengenai fuzzy support vector machine (FSVM) pada data microarray diperoleh hasil tingkat akurasi yang cukup tinggi dibandingkan metode klasifikasi lainnya seperti SVM, ANN, CART, maupun analisis diskriminan untuk klasifikasi data "prostate cancer". Selain itu, diperoleh kesimpulan performansi model FSVM dengan atau tanpa feature selection yaitu tingkat akurasi model FSVM dengan feature selection SNR lebih tinggi dibandingkan model FSVM dengan feature selection SVM-RFE dan tanpafeature selection [6].

Metode klasifikasi yang digunakan dalam penelitian ini adalah Fuzzy Support Vector Machine (FSVM) dengan atau tanpa seleksi variabel menggunakan fast correlation based filter. Dalam penelitian ini juga akan dibandingkan kinerja Algoritma Genetika dibandingkan grid search dalam memperoleh parameter SVM yang optimum berdasarkan tingkat ketepatan klasifikasi. Algoritma Genetika menunjukkan kinerja yang baik dalam memperoleh solusi yang global optimum dan mudah dihibridisasi dengan metode 
lain [7]. Tujuan klasifikasi ini antara lain adalah apabila ingin memprediksi pasien terkena kanker atau tidak bisa menggunakan gen yang sudah terseleksi saja tanpa mengambil 6033 gen. Hal tersebut dilakukan untuk me-minimalisir biaya yang dikeluarkan.

\section{TINJAUAN PUSTAKA}

\section{A. Support Vector Machine (SVM)}

SVM merupakan suatu metode machinelearning yang bekerja atas dasar prinsip Structural Risk Minimization dengan tujuan menemukan hyperplane terbaik yang memisahkan dua buah class pada input space [8]. Inti dari proses pembelajaran pada SVM adalah mendapatkan lokasi hyperplane [9]. Terdapat tiga penjelasan mengenai SVM yaitu dapat dijelaskan sebagai berikut.

1. SVM pada Linear Separable Data

SVMLinearly separabledata merupakan data yang dapat dipisahkan secara linier. Misalkan $x_{i}=\left\{x_{i}, x_{i+1}, \ldots, x_{n}\right\}$ adalah dataset dan $y_{i}=\{+1,-1\}$ adalah label kate-gori untuk dataset. Pada klasifikasi linear, SVM dapat dibedakan menjadi dua yaitu linearly separable dan linearly nonseparable.Pada Gambar 2.1 dapat dilihat ilustrasi li-nier separable case.

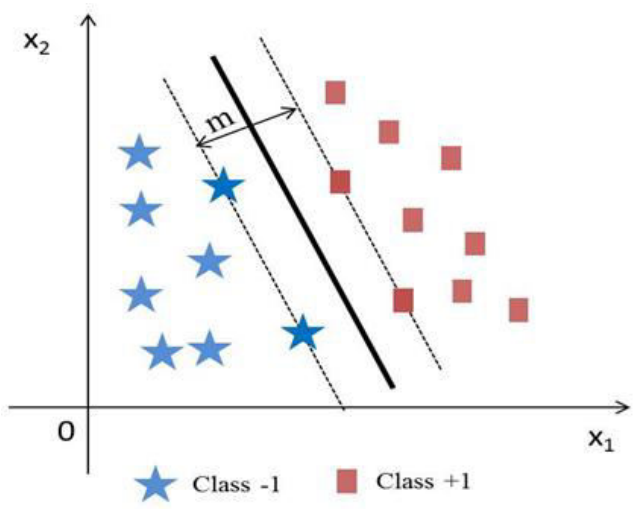

Gambar 1. Konsep Hyperplane pada SVM.

Gambar 1 menunjukkan garis putus-putus merupakan bidang membatas kelas -1 dan kelas +1 . Garis tegas lurus diantara garis putus-putus merupakan bidang pemisah antara kelas +1 dan kelas -1.Persamaanhyperplane dapat ditulis seperti persamaan (1)

$$
\boldsymbol{w}^{T} \mathbf{x}+b=0
$$

$\boldsymbol{w}$ : vektor bobot (weight vector)

$b:$ konstanta.

Nilai margin antara bidang pembatas adalah $\frac{2}{\|\boldsymbol{w}\|}$

\section{SVM pada Linear Non-Separable Data}

Pada beberapa kenyataan, besar kemungkinan terjadi misclasification. Mengatasi hal tersebut maka dilakukan klasifikasi linear non separable dengan beberapa pengembangan. Masalah optimasi baik pada fungsi obyektif maupun kendala dimodifikasi dengan variabel slack $\xi>0$ merupakan sebuah ukuran kesalahan klasifikasi [10]. Penyele-saian untuk kasus linear SVM non separable adalah diperoleh hyperplane pemisah yang optimal

$$
f(\mathbf{x})=\sum_{i, j=1}^{n} \alpha_{i} y_{i} \mathbf{x}_{i}^{T} \mathbf{x}_{j}+b
$$

3. SVM pada Non-Linearly Separable Data dengan Menggunakan Metode Kernel

SVM pada Non-linearly separabledata, merupakan data nonlinear yang dapat dipisahkan tetapi memerlukan metode tersendiri dalam penyelesaiannya. Penyelesaian data jenis ini dapat dilakukan dengan menggunakan SVM yang di kombinasikan dengan metode kernel. Metode kernel mentransformasikan data ke dalam dimensi ruang fitur sehingga dapat dipisahkan secara linier pada fitur space.

KernelRBF direkomendasikan untuk diuji pertama kali. Hal ini dikarenakan fungsi kernel RBF memiliki performansi yang sama dengan kernel linier pada parameter tertentu [11].

Tabel 1.

Fungsi Kernel pada SVM Non-linier

\begin{tabular}{cc}
\hline \hline Fungsi Kernel & Fungsi pembentuk matriks kernel \\
\hline Linier & $K\left(x_{i}, x_{j}\right)=x_{i}{ }^{T} x_{j}$ \\
RBF & $K\left(x_{i}, x_{j}\right)=\exp \left(-\gamma\left\|x_{i}-x_{j}\right\|^{2}\right), \gamma>0$ \\
Polinomial & $K\left(x_{i}, x_{j}\right)=\left(x_{i}{ }^{T} x_{j}+1\right)^{p}, p=1, \ldots, z$
\end{tabular}

\section{B. Fuzzy Support Vector Machines (FSVM)}

Titik kunci dalam metodeFuzzy Support Vector Machines (FSVM) adalah menetukan fungsi keanggotaan fuzzy. Pada metode Fuzzy Support Vector Machines (FSVM) masih memiliki kelemahan dalam menangani data imbalanced. Terdapat beberapa penerapan yang hanya fokus pada akurasi untuk klasifikasi suatu kelas. Misalkan diberikan rangkaian training sebagai berikut [12].

$$
\left(y_{1}, x_{1}, s_{1}\right), \ldots .,\left(y_{n}, x_{n}, s_{n}\right)
$$

Keanggotaanfuzzy $s_{i}$ menjadi fungsi pada kelas $y_{i}$ yaitu $s_{i}=1$ jika $y_{i}=1$ dan $s_{i}=0,1$ jika $y_{i}=-1$. Fungsi keputusan untuk FSVM dituliskan dalam persamaan (4)

$$
f(\mathbf{x})=\sum_{i, j=1}^{n} \alpha_{i} y_{i} K\left(\mathbf{x}_{i} \mathbf{x}_{j}\right)+b
$$

dimana $0 \leq \alpha_{i} \leq s_{i} C, \quad i=1,2, \ldots, n$

\section{Algoritma Genetika}

Konsep dasar yang mengilhami timbulnya algoritma genetika adalah teori evolusi alam. Dikarenakan algoritma genetika diilhami oleh ilmu genetik maka istilah yang dipergunakan dalam algoritma genetika banyak diadaptasi dari ilmu tersebut [13]. Terdapat beberapa langkah dalam melakukan analisis menggunakan algotima genetika: [14].

1. Menentukan pengaturan dari operator algoritma genetika yang cocok dengan masa-lah yang akan dianalisis.

2. Melakukan proses initialisasi.

3. Mendapatkan nilai fitness $f(u)$ pada tiap kromosom $v_{u}$ dalampopulasi. 
4. Mengevaluasi nilai fitness $f(u)$ pada tiap kromosom $v_{u}$ dalam populasi.

5. Menerapkan seleksi roulettewheel. Tahapan seleksi roulettewheel adalah mengitung nilai fitness masingmasing kromosom $v_{u}$, menghitung total nilai fitness, menghitung proporsi masing-masing kromosom, menghitung nilai kumulatif proporsi untuk tiap kromosom, membangkitkan sebuah $r_{n}$ angka dengan range $[0,1]$.Jika $r_{n} \leq S_{1}$, maka kromosom $v_{1}$ yang dipilih, lalu selainnya $v_{u}$ yang dipilih, sehingga $S_{u-1}<r_{n} \leq S_{u}$.

6. Melakukan pindah silang (Crossover).

7. Melakukanproses mutasi dimana mutasi diterapkan dengan probabilitas $P_{m}$.

8. Melakukan proses elitisme

9. Melakukan pergantian antara nilai fitness dengan keturunan baru.

10. Berhenti ketika nilai fitness sudah konvergen dan kembali ke solusi terbaik dalam populasi saat ini jika kriteria telah terpenuhi, jika belum kembali ke Langkah 3.

\section{Fast Corelation Based Filter (FCBF)}

Fast Corelation Based Filter merupakan salah satu algoritma feature selection yang bersifat multivariat dan mengukur kelas fitur dan korelasi antara fitur-fitur [15]. Terdapat dua pendekatan denganmengukur korelasi antara dua variabel acakyaitu berdasar pada classical linearcorrelation/linear correlation coefficientdan berdasarkan pada informationtheorical concept of entropy.

\section{E. K-Fold Cross Validation}

Metode validasi dengan k-folds sangat cocok digunakan untuk kasus data yang jumlah sampelnya terbatas. Dalam kfolds cros validation, data (D) dibagi ke dalam $\mathrm{k}$ subsets data $\mathrm{D}_{1}, \mathrm{D}_{2}, \ldots, \mathrm{D}_{\mathrm{k}}$ dengan jumlah yang sama. Data yang digunakan untuk training adalah subsets data k-1 yang dikombinasikan secara bersama-sama dan kemudian diaplikasikan untuk sisa satu subsets data sebagai hasil testing. Proses ini diulangi sebanyak $\mathrm{k}$ subsets dan hasil akurasi klasifikasi yaitu hasil rata-rata dari setiap data training dan testing [16].

\section{F. Evaluasi Performasi Klasifikasi}

Evaluasi performasi klasifikasi yaitu dilakukan perhitungan akurasi klasikasi dengan confusion matrix digunakan untuk komposisi data yang balance. Tabelklasifikasi untuk pengukuran performa klasifikasi ditunjukkan dalam Tabel 2.

Tabel 2.

Tabel Klasifikasi

\begin{tabular}{ccc}
\hline \hline \multirow{2}{*}{ Riil } & \multicolumn{2}{c}{ Prediksi } \\
\cline { 2 - 3 } & Positif & Negatif \\
\hline Positif & $T P$ & $F N$ \\
Negatif & $F P$ & $T N$ \\
\hline \hline
\end{tabular}

Keterangan :

TP : True Positive ( jumlahprediksibenarpadakelaspositif)

FP : False Positive (jumlahprediksisalahpadakelaspositif)

$F N$ : False Negative (jumlahprediksisalahpadakelasnegatif)

$T N$ : True Negative (jumlahprediksibenarpadakelasnegatif)

Berdasarkan Tabel 2, perhitungan akurasi dapat dilakukan dengan rumus sebagai berikut.

$$
\text { Akurasi }=\frac{T N+T P}{T N+T P+F N+F P}
$$

Sensitivitasmerupakanakurasikelaspositifsedangkanspesi-

fisitasmerupakanakurasipadakelasnegatif [8].

\section{G. Microarray Data}

Micorarray mampu menentukan ekspresi ribuan gen dan secara simultan memantau proses bilogis yang sedang berlangsung [3].Selanjutnya ekspresi dari ribuan gen yang merepresentasikan suatu jaringan pada manusia, akan diklasifikasikan sebagai jaringan kanker atau bukan khususnya pada penyakit prostate. Karakteristik microarray data adalah jumlah data sedikit dan jumlah variabelyang sangat banyak sedangkan jumlah data sedikit karena harga untuk mendapatkan data sangat mahal.Data ini berisi informasi gen karena itu jumlahvariabel-nya sangat banyak. Berikut ini gambaran mengenai proses terbentuknya data microarray.

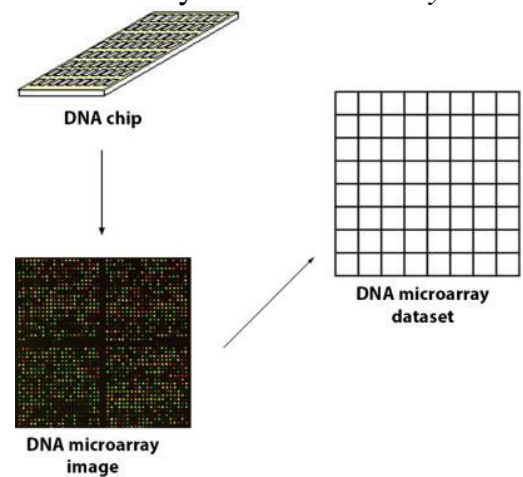

Gambar 2. Ekspresi Gen Microarray [15].

\section{H. Prostat}

Prostat merupakan kelenjar seukuran buah kenari yang terdapat di dalam sistem reproduksi pria, yang terletak di antara leher kandung kemih dan saluran kemih (uretra).Prostat mengeluarkan cairan berwarna putih yang memberi nutrisi dan mengangkut sperma, yang disebut sebagai semen. Hormon pria yang disekresi oleh testis secara langsung memengaruhi pertumbuhan dan fungsi prostat.Kasus prostat yang bengkak umum terjadi di kalangan pria paruh baya dan lanjut usia, namun sebagian besar kasus yang terjadi merupakan hiperplasia jinak (peningkatan jumlah sel yang tidak normal) [17].

\section{METODOLOGI PENELITIAN}

\section{A. Sumber Data}

Data yang digunakan dalam penelitian ini adalah data jenis microarray "prostate cancer" dari penelitian yang dilakukan di Florida pada Maret 2002 [18].

\section{B. Variabel Penelitian}

Variabel penelitian yang digunakan dalam penelitian disajikan dalam Tabel 3.

Tabel 3.

Variabel Penelitian

\begin{tabular}{lcccc}
\hline \hline \multirow{2}{*}{ Dataset } & \multirow{2}{*}{$\begin{array}{c}\text { Banyak } \\
\text { Variabel }\end{array}$} & \multirow{2}{*}{$\begin{array}{c}\text { Banyak } \\
\text { Class }\end{array}$} & $\begin{array}{c}\text { Tumor } \\
\text { prostate (1) }\end{array}$ & Normal (0) \\
\hline Prostate & 6033 & 2 & 52 & 50 \\
\hline \hline
\end{tabular}


Struktur data prostate dapat ditunjukkan melalui Tabel 4.

Tabel 4.

Struktur Data Prostate

\begin{tabular}{cccccc}
\hline $\begin{array}{c}\text { Pengamatan } \\
\text { ke- }\end{array}$ & $\mathrm{X}_{1}$ & $\mathrm{X}_{2}$ & $\ldots$ & $\mathrm{X}_{6033}$ & $\mathrm{Y}$ \\
\hline 1 & $\mathrm{X}_{1(1)}$ & $\mathrm{X}_{1(2)}$ & $\ldots$ & $\mathrm{X}_{1(6033)}$ & 1 \\
2 & $\mathrm{X}_{2(1)}$ & $\mathrm{X}_{2(2)}$ & $\cdots$ & $\mathrm{X}_{2(6033)}$ & 1 \\
3 & $\mathrm{X}_{3(1)}$ & $\mathrm{X}_{3(2)}$ & $\cdots$ & $\mathrm{X}_{3(6033)}$ & 1 \\
$\cdot$ & $\cdot$ & $\cdot$ & $\cdot$ & $\cdot$ & $\cdot$ \\
$\cdot$ & $\cdot$ & $\cdot$ & $\cdot$ & $\cdot$ & $\cdot$ \\
. & $\cdot$ & $\cdot$ & $\cdot$ & $\cdot$ &. \\
102 & $\mathrm{X}_{102(1)}$ & $\mathrm{X}_{102(2)}$ & $\ldots$ & $\mathrm{X}_{102(6033)}$ & 0 \\
\hline \hline
\end{tabular}

Keterangan:

$\mathrm{X}:$ Jenis Gen

$\mathrm{Y}:$ Pasien

\section{Langkah Analisis}

Langkahanalisisyang disusun untuk melakukan penelitianiniadalahsebagaiberikut.

1. Mendeskripsikan data microarray "Prostate".

2. Melakukan feature selection menggunakan metode FCBF.

3. Menentukan fungsi kernel yang digunakan yaitu kernel RBF

4. Membagi data training dan testing menggunakan 10-fold cross validation.

5. Analisis klasifikasi menggunakan metode Grid Search FSVM pada data microarray "Prostatecancer".

a. Mendapatkan parameter yang optimal dengan nilai cost $(C)$ berada diantara $2^{-5}, 2^{-4}, 2^{-3}, \ldots, 2^{13}, 2^{14}, 2^{15}$, 100,1000 dan nilai gamma $(\gamma)$ diantara $2^{-15}, 2^{-14}, 2^{-}$ ${ }^{13}, \ldots, 2^{1}, 2^{2}, 2^{3}$

b. Melakukan klasifikasi FSVM dengan kombi-nasi nilai parameter $C$ dan $\gamma$.

c. Menghitung akurasi klasifikasi

d. Menentukan nilai parameter optimal $C$ dan $\gamma$ dari seluruh kombinasi parameter mengguna-kan data training.

e. Menghitung performa klasifikasi menggunakan data testing.

6. Analisis klasifikasi menggunakan FSVM-GA pada data microarray "Prostatecancer".

7. Melakukan perbandingan hasil klasifikasi metode Grid Search FSVM dengan FSVM-GA dengan seleksi atau tanpa seleksi.

8. Menarik kesimpulan dan saran.

\section{ANALISIS DAN PEMBAHASAN}

Hasil performansi klasifikasi berupa nilai akurasi yang diperoleh pada metode FSVM dan optimasi genetic algorithm dengan atau tanpa feature selection FCBF pada data microarray "prostate cancer".

\section{A. Karakteristik Data Microarray Prostate Cancer}

Data microarray prostate cancer terdiri 6033 variabel, dua kategori kelas, dan 102 observasi yang berasal dari ekspresi gen pasien prostate.

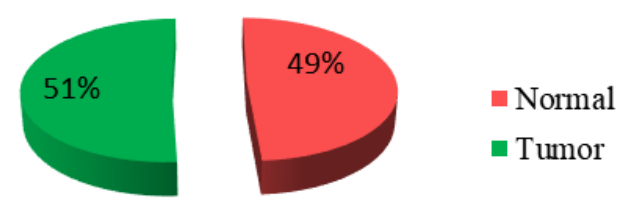

Gambar 3. Piechart Proporsi Tiap Kategori

Gambar3 terlihat bahwa proporsi tiap kategori memiliki proporsi yang hampir sama (balance), dari 102 pasien kanker prostat sebanyak $51 \%$ pasien masuk dalam kelas tumor atau sebanyak 52 pasien dan $49 \%$ pasien masuk dalam kelas normal. Berikut akan ditampilkan penyebaran prostate datasetsuntuk beberapa feature atau gen.

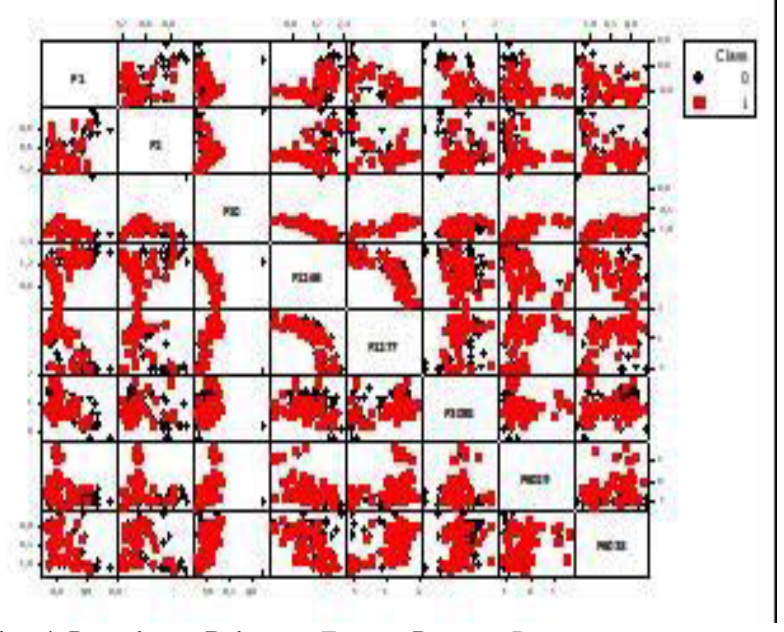

Gambar 4. Penyebaran Beberapa Feature Prostate Datasets.

Gambar 4 didapatkan bahwa data untuk tiap kelas tersebar secara merata, hal tersebut akan mempersulit dalam melakukan proses klasifikasi, sehingga diperlukan fungsi pemisah atau hyperplane untuk mempermudah proses klasifikasi data. Proses pemisahan data prostat tidak bisa dipidahkan secara linear, sehingga diperlukan pemisah untuk data secara tidak linier dengan meng-gunakan metode kernel.

\section{B. Klasifikasi Data Microarray Prostate Cancer dengan Menggunakan Metode FSVM Tanpa Seleksi Variabel}

Sebelum melakukan analisis FSVM, maka dilakukan partisi data menjadi data training dan data testing dengan proporsi 90:10. Pembagiannya menggunakan 10-fold.Selanjutnya akan dilakukan analisis klasifikasi dengan menggunakan metode FSVM dengan mencari parameter yang optimal dengan nilai cost berada diantara $2^{-5}, 2^{-4}, 2^{-3}, \ldots, 2^{13}, 2^{14}, 2^{15}$, 100,1000 dan nilai gamma diantara $2^{-15}, 2^{-14}, 2^{-13}, \ldots, 2^{1}, 2^{2}, 2^{3}$. Sehingga diperoleh jumlah kombinasi cost dan gamma sebanyak 437 kombinasi atau melakukan running data sebanyak 437 kali.Didapatkan nilai cost dan gamma yang paling optimal dari data training adalah $2^{9}, 1000$ dan $2^{-15}, 2^{-14}$ dengan nilai rata-rata akurasinya sebesar $100 \%$.Hasil ukuran performansi yang didapat dari parameter cost dan gamma 
yang optimaldiperoleh akurasi sebesar 90,18\% menggambarkan kemampuan dalam membedakan sampel berdasarkan kelas dan sisanya masuk dalam kesalahan klasifikasi.

C. Klasifikasi Data Microarray Prostate Cancer Menggunakan Metode FSVMdengan Genetic Algorithm (GA)

Pada subbab ini akan dibahas mengenai klasifikasi data prostate cancer dengan seleksi maupun tanpa seleksi FCBF. Hasil seleksi variabel dengan FCBF menghasilkan 29 variabel yang terselksi. Diperoleh nilai cost dan gamma yang paling optimal terdapat pada $2^{10}$ dan $2^{-4}$ dengan nilai rata-rata akurasinya sebesar $97 \%$.Ringkasan tabel untuk nilai akurasi, spesifitas, dan sensitifitas data testing dari parameter yang optimal disajikan dalam Tabel 5.

Tabel 5.

Ukuran Performansi untuk Parameter Optimal

\begin{tabular}{cccc}
\hline \hline Fold & Akurasi & Sensitifitas & Spesifitas \\
\hline 1 & 0,9090909 & 1 & 0,8333333 \\
2 & 1 & 1 & 1 \\
3 & 1 & 1 & 0 \\
4 & 0,9 & 0,8 & 1 \\
5 & 0,9 & 0,8 & 1 \\
6 & 1 & 1 & 1 \\
7 & 0,9 & 0,8 & 1 \\
8 & 1 & 1 & 1 \\
9 & 0,9 & 0,8 & 1 \\
10 & 0,9 & 1 & 0,8 \\
\hline Rata- & 0,9409091 & 0,92 & 0,8633333 \\
rata & & & \\
\hline \hline
\end{tabular}

Tabel 5 menunjukkan ukuran performansi yang didapat dari parameter cost dan gamma yang optimal. Diperoleh nilai akurasi sebesar 94,09\% menggambarkan ke-mampuan dalam membedakan sampel berdasarkan kelas dan sisanya masuk dalam kesalahan klasifikasi. Nilai sensitifitas sebesar 92\%, ini menunjukkan bahwa sampel mampu membe-dakan kelas tumor dengan benar. Nilai spesifitas menunjukkan sampel mampu membedakan kelas normal dengan benar sebesar 86,3\%.

Selanjutnya otimasi parameter GA yang berasal dari seleksi atau tanpa seleksi variabel menggunakan metode FCBF. Langkah pertama yaitu melakukan inisialisasi kromosom sebanyak 100. Nilai parameter optimal $C$ sebesar 1024 dan nilai parameter $\gamma$ sebesar 0,0625. Berikut ini adalah gambaran mengenai ilustrasi optimasi GA dalam Gambar 5.

\begin{tabular}{|c|c|c|c|c|}
\hline & \multirow{2}{*}{\multicolumn{2}{|c|}{$\begin{array}{l}\text { Parameter } \\
\text { Kromosom }\end{array}$}} & \multirow{2}{*}{$\frac{\gamma}{0,0625}$} & \\
\hline & & & & \\
\hline $\begin{array}{c}\text { Kromosom } \\
\text { Ke- }\end{array}$ & Fitness & $\begin{array}{c}\text { Proporsi } \\
\text { Nilai Fitness } \\
\end{array}$ & $\begin{array}{c}\text { Nilai Fitness } \\
\text { Kumulatif } \\
\end{array}$ & $\begin{array}{l}\text { Random } \\
\text { Number }\end{array}$ \\
\hline 1 & 0,9878 & 0,011 & 0,011 & 0,08 \\
\hline 2 & 0,9754 & 0,0108 & 0,0218 & 0,031 \\
\hline$\vdots$ & $\vdots$ & $\vdots$ & $\vdots$ & $\vdots$ \\
\hline 100 & 0,7090 & 0,0079 & 1,0000 & 0,056 \\
\hline
\end{tabular}

Gambar 5. Ilustrasi Optimasi GA.

Setelah selesai melakukan proses seleksi, selanjutnya melakukan proses pindah silang atau crossover yaitu menghasilkan kromosom baru dari hasil perpaduan 2 kromosom orang tua.

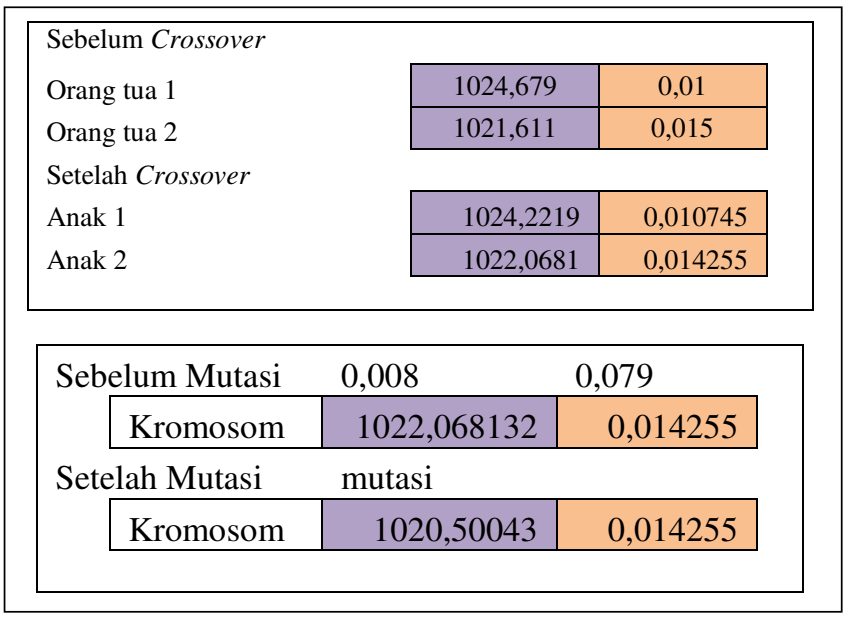

Gambar 5. Ilustrasi Optimasi GA (Lanjutan)

Apabila sudah dilakukan proses pindah silang maka dilanjutkan dengan proses mutasi. Proses mutasi dengan membandingkan antara nilai probabilitas mutasi $\left(P_{\mathrm{m}}\right)$ sebesar 0,01 . Jika nilai bilangan random lebih kecil dibandingkan probabilitas mutasi, maka gen yang bersesuaian akan mengalami mutasi dengan cara mengganti gen tersebut dengan bilangan random. Dilanjutkan dengan proses elitisme dalam Gambar 6 untuk mempertahankan kromosom terbaik dalam populasi dengan melihat nilai fitness tertinggi untuk generasi selanjutnya. Kromosom yang dipertahankan sebesar 5\% dari total kromosom dalam populasi yaitu sebanyak 5 kromosom.

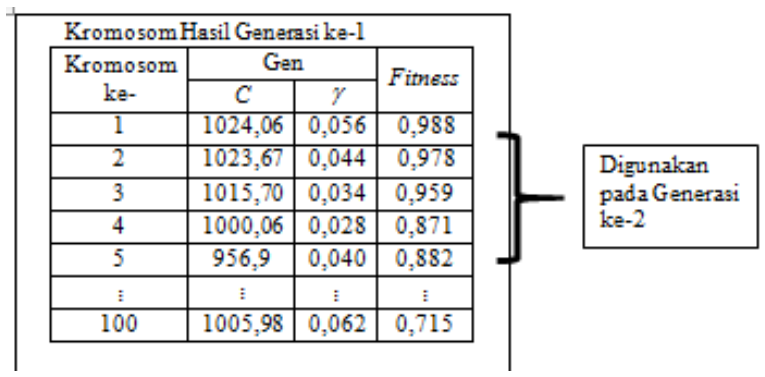

Gambar 6. Ilustrasi Etilisme Optimasi GA.

Kromosom yang dipertahankan sebesar 5\% dari total kromosom. Nilai fitness tertinggi dari generasi ke-1 digunakan untuk kromosom awal generasi ke-2. Sedangkan kromosom hasil generasi ke-2 digunakan untuk kromosom awal pada generasi ke-3. Proses optimasi parameter dengan algoritma genetika dilanjutkan hingga mendapatkan nilai fitness yang konvergen.

Perbandingan hasil klasifikasi menggunakan metode Grid Search FSVM dengan GA-FSVM dengan atau tanpa seleksi FCBF.

Tabel 7.

Perbandingan Hasil Klasifikasi

\begin{tabular}{ccc}
\hline \hline & Metode & Akurasi \\
\hline Tanpa & Grid Search FSVM & $90,18 \%$ \\
Seleksi & GA-FSVM & $76,45 \%$ \\
Seleksi & Grid Search FSVM & $94,09 \%$ \\
FCBF & GA-FSVM & $99 \%$ \\
\hline \hline
\end{tabular}

Tabel 7 menunjukkan nilai akurasi klasifikasi FSVM dengan menggunakan seleksi dan optimasi genetic algorithm lebih tinggi dibandingkan tanpa seleksi.. Hasil klasifikasi FSVM dengan seleksi FCBF tanpa optimasi genetic algorithm 
menghasilkan nilai akurasi lebih tinggi dibandingkan tanpa seleksi.

\section{KESIMPULAN DAN SARAN}

Kesimpulanyang diperoleh dari hasil analisis yang dilakukan adalah karakteristik data proporsi tiap kategori memiliki proporsi yang hampir sama (balance), dari 102 pasien kanker prostat sebanyak $51 \%$ pasien masuk dalam kelas tumor atau sebanyak 52 pasien dan $49 \%$ pasien masuk dalam kelas normal.Pada klasifikasi data prostate cancer didapatkan nilai cost dan gamma yang paling optimal terdapat pada $2^{9}$ dan $2^{-15}$ dengan hasil ukuran performansi akurasinya sebesar 90,18\%. Didapatkan nilai sensitifitas sebesar $86 \%$ menunjukkan bahwa sampel mampu membedakan kelas tumor dengan benar.Nilai akurasi klasifikasi FSVM dengan menggunakan seleksi dan optimasi genetic algorithm lebih tinggi dibandingkan tanpa seleksi.

Saran yang bisa diberikan yaitu melakukan penelitian dengan menggunakan simulasi data dengan berbagai karakteristik data, sehingga dapat diketahui kinerja algoritma genetika bukan hanya untuk optimasi tetapi seleksi variabel berdasarkan karakteristik data yang telah disimulasikan.

\section{DAFTAR PUSTAKA}

[1] Kemenkes, "Situasi Penyakit Kanker," Bul. Jendela Data dan Inf. Kesehat., pp. 1-35, 2015.

[2] V. R. Solang, A. Monoarfa, and F. Tjandra, "Profil penderita kanker prostat di RSUP Prof. Dr. R. D. Kandou Manado periode tahun 2013-2015," J. e-Clinic, vol. 4, no. 2, 2016.

[3] P. T. Ramadhani, U. N. Wisesty, and A. Aditsania, "Deteksi Kanker Berdasarkan Klasifikasi Data Microarray Menggunakan Functional Link Neural Network de-ngan Seleksi Fitur Genetic Algorithm," Ind. J. Comput., vol. 2, no. 2, pp. 11-22, 2017.

[4] L. Yu and H. Liu, "Feature Selection for High-Dimensional Data: A
Fast Correla-tion-Based Filter Solution," in Proceedings of the Twentieth International Conference on Machine Learning (ICML), 2003.

[5] R. Hermawan, A. P. Kurniati, and Suyanto, "Analisis Dan Implementasi Feature Selection Menggunakan Algoritma Fuzzy Support Vector Machine(FSVM)," Tek. Inform., pp. 1-37.

[6] M. Hajiloo, H. R. Rabiee, and M. Anooshahpour, "Fuzzy support vector machine: an efficient rule based classification technique for microarrays," Bioinformatics, pp. 1-11, 2013.

[7] Z. Ismail and Irhamah, "Genetic Algorithm and Tabu Search for Vehicle Routing Problems with Stochastic Demand," in AIP Conference Proceedings, 2010.

[8] R. Feldman and J. Sanger, The Text Mining Hand Book. New York: Cambridge University Press, 2007.

[9] dan D. H. Nugroho, Anto S., Arief Budi W., "Support Vector Machine "Teori dan Aplikasinya dalam Bioinformatika," IlmuKomputer.Com, 2003. .

[10] S. Gunn, "Support Vector Machines for Classification and Regression," Southampton, 1998.

[11] C.-W. Hsu, C.-C. Chang, and C.-J. Lin, "A Practical Guide to Support Vector Classification," Taiwan, 2003.

[12] C. Lin and S. Wang, "Fuzzy Support Vector Machines," IEEE Trans. Neural Net-work, pp. 464-471, 2002.

[13] K. Setiawan, Paradigma Sistem Cerdas. Malang: Bayumedia, 2003.

[14] Z. Ismail and Irhamah, "Solving the Vehicle Routing Problem with Stochastic Demands via Hybrid Genetic Algorithm-Tabu Search," J. Math. Statictics, pp. 161-167, 2008.

[15] A. Alonso, S. Noelia, and B. Veronica, Feature Selection for HighDimensional Data. Artificial Intelligence: Foundations, Theory, and Algorithms. Switzerland: Springer International Publishing Switzerland, 2015.

[16] V. B. Canedo, N. S. Marono, A. A. Betanzos, J. Benitez, and F. Herrera, "A Review of Microarray Datasets and Applied Feature Selection Methods," Inf. Sci., pp. 111-135, 2014.

[17] H. Cheng, "Kanker Prostat," 2017. [Online]. Available: https://www21.ha.org.hk/smartpatient/EM/MediaLibraries/EM/Dise ases/Cancer/Prostate Cancer/Cancer-Prostate-CancerIndonesian.pdf?ext=.pdf. [Accessed: 19-Jul-2018].

[18] D. Singh, P. G. Febbo, K. Ross, D. G. Jackson, J. Manola, and C. Ladd, "Gene expression correlates of clinical prostate cancer behavior," Cancer Cell, vol. 1, pp. 203-209, 2002. 